\title{
Multiple levels of analysis and the limitations of methodological individualisms*
}

\author{
Ronald Jepperson (University of Tulsa) \\ and \\ John W. Meyer (Stanford University) \\ January 2010
}

Shorter version forthcoming in Sociological Theory.

* Corresponding author: R. Jepperson, Dept. of Sociology, Chapman Hall, Univ. of Tulsa, Tulsa OK 74104 (ronald-jepperson@utulsa.edu). We have benefited from comments provided by Albert Bergesen, John Boli, Marion Fourcade-Gourinchas, David Frank, Kyriakos Kontopoulos, Peter Meyer, Francisco Ramirez, Evan Schofer, and Ann Swidler. The paper also draws from past conversations with S.N. Eisenstadt, Edgar Kiser, and Morris Zelditch Jr. The analysis reflects our work on previous related projects (Meyer and Jepperson 2000 and Jepperson and Meyer 2007). 


\title{
Multiple levels of analysis and the limitations of methodological individualisms
}

\author{
$\underline{\text { Abstract }}$ \\ We provide a substantive treatment of the relations of the multiple levels of analysis \\ involved in macro-sociological explanation-i.e., the relations of individual, structural, \\ and institutional processes. The paper also criticizes the doctrinal insistence upon single- \\ level individualistic explanation found in some prominent contemporary metatheory. For \\ illustrative material the article returns to intellectual uses of Weber's "Protestant Ethic \\ thesis," showing how an artificial version has been employed as a kind of proof text for \\ the alleged scientific necessity of individualist explanation. The core of the article \\ provides an alternative exposition. We render the discussion of Protestantism and \\ capitalism in an explicitly multi-level way, differentiating possible individual-level, \\ social-organizational, and institutional linkages. The causal processes involved are \\ distinct ones, with the more structural and institutional forms neither captured by \\ individual-level processes nor realistically attainable via individual-level thinking. We \\ argue more generally that "methodological individualisms" confuse issues of explanation \\ with issues about microfoundations. This persistent intellectual conflation seems rooted \\ in the broad folk models of contemporary liberal individualistic societies.
}




\section{INTRODUCTION}

Sociology is partly constituted by ideas of "emergent properties" and multiple levels of analysis. These ideas have been discussed continuously throughout the entire history of the discipline. We refer to the expansive literatures on "social facts," structural effects, micro- and macro-levels, structures and agents, and the like. These literatures have been epitomized in reviews (for example, Knorr-Cetina 1981, Alexander and Giesen 1987, Münch and Smelser 1987, Blau 1974, Turner and Boyns 2002, Mayntz 2003), and reflected upon by well-informed philosophers (for example, Garfinkel 1981, Bhargava 1992, Kincaid 1996, Bunge 1996, Fodor 1997, Little 2007).

Yet substantial ambiguity still surrounds one absolutely central analytical issue — the issue that motivates this article. The issue, in a phrase, is: "Is there such a thing as macro-macro causation?" (Little 2007: 362). Spelled out: Are there fully macroscopic explanations-explanations linking one "macro-" property to another macro-property that are separate from explanations that link one macro-property to another via microcausal pathways? If so, what is the nature of the difference?

Readers are undoubtedly familiar with one way in which the issue has been illustrated recently; we refer to the so-called "Boudon-Coleman diagram" (the label is Bunge's, 1996, reflecting Boudon 1981). So, in Figure 1, does the direct macro-macro link-arrow 4--represent a distinctive and legitimate set of causal linkages? Or is that arrow a stand- 
in to be dispensed with when a macro-to-micro-to-macro pathway--arrows 1, 2, and 3--is provided?

\section{<FIGURE 1 ABOUT HERE>}

Coleman himself draws in a direct macro-to-macro connection in some of his diagrams, but then drops it to focus upon the macro-to-micro-to-macro pathway. The relationship of the direct macro-to-macro arrow to the individualistic pathway is not discussed (see especially Coleman 1987). A related treatment by Hartmut Esser on “explanatory sociology" (Esser 1994) also includes a direct macro-to-macro arrow, but it is never mentioned subsequently. Sociology is multi-level, Esser says, but causation occurs only at the bottom. What this means is left unexplained.

In contrast, Hedström and Swedberg in an oft-cited treatment do not include any macrolevel connection in their Boudon-Coleman variant--even though they offer their diagram as a general "typology of social mechanisms" (Hedström and Swedberg 1998: 21ff). System-level properties are linked exclusively via the micro-pathway.

Given the centrality of the issue for sociology as a discipline, the murkiness regarding the direct macro-level linkage is striking. Many discussions acknowledge that a direct macro-macro connection is empirically present in some sense. But rarely does one find a clear sense of what that means, or a clear treatment of the differences- if any-between the different pathways pictured in the Boudon-Coleman diagram. If anything, the 
"microchauvinist" interpretation (Turner and Boyns 2002) offered by Hedström and Swedberg has become a kind of default interpretation.

The main overviews of the "macro-micro connection," cited above, do not directly address this core issue by working with actual sociological explanations-they are mostly metatheoretical treatments. Sawyer in a recent review can then indict sociologists for failing to provide a clear account of structural causation (2002: 219). Recent reviews by philosophers can claim that the discussion remains confused (Zahle 2007: 334-336) and that the whole issue requires "fresh thinking" (Little 2007: 344). (Treatments that do partly address the specific issue using substantive sociological material include Collins 1981, Münch 1987, Collins 1988, Stinchcombe 1991, Hannan 1992, and Kontopoulos 1993.)

We address the central theoretical lacuna in this article. Specifically, we attempt to provide a clear exposition of multi-level explanation, showing with substantive examples that there are macro-level causal pathways that are distinct from micro-level ones. We seek to provide more specification and illustration than is typically available of structural levels of analysis, of the nature of the causal arguments at these levels, and of the relations of more structural (and institutional) levels to the individual-level of analysis. In so doing we also provide a rebuttal to a fundamental element of methodological individualism: the idea that more structural arguments are at best merely "explanation sketches," or temporary stand-ins for a later proper individualist analysis. 
To undertake this task we take advantage of a discursive opportunity provided by Coleman (e.g., 1987, 1990, and elsewhere) and his intellectual colleagues. We refer to Coleman's use of Figure 1 to render Max Weber's "Protestant Ethic thesis" ([1904/5] 1996) as a proof text for individualistic explanation. We criticize this usage. Further, we offer a contrasting multi-level schema for summarizing the substantive historical discussion of Weber's topic--the connections between Protestantism and capitalist development. We see such a schema as having general theoretical utility.

In our substantive discussion we will draw upon Eisenstadt's still-valuable summary of the macrohistorical literature on Weber's question: namely, that Protestantism involved broad changes in entire systems of rules and entire sets of $\underline{\text { roles, }}$, as well as changes in motivations (Eisenstadt 1965, 1968b). That is, for this explanatory problem, it is entirely reasonable to hypothesize that changed religious ideas affected individual economic goals, and subsequently changed whole economies. (The famous individual-level argument.) But changed religious rules and roles also altered the social organization of economic life- via a distinct set of causal processes. And, at an institutional level, the changed religious institutions and cosmologies of a whole society altered the entire set of rules governing economic life-another distinct set. That is, causal processes at multiple levels are in all likelihood involved for the topic at hand, and there is every reason to see these different causal processes as having independent explanatory import.

Continuing with this classic example, we will argue that methodological individualisms confuse explanation with attention to the microfoundations of social life. Of course all 
causal social processes work through the behaviors and ideas of individual persons- this “ontological truism” (Watkins 1952) is a basic premise of all post-Hegelian naturalist social science. But this premise (sometimes called "ontological individualism" by philosophers) in no way necessitates an explanatory (or "methodological") individualism. (See Bhargava 1992, Kincaid 1996, Bunge 1996, Fodor 1997, and Sawyer 2002 for philosophical development of this fundamental point.) The latter is just one program for social science, and there is no reason that it should have any privileged status in social scientific work.

Developing this idea, we build also upon the related idea, stressed by Stinchcombe and reinforced recently by Sawyer, that the levels of analysis featured in a sociological explanation should be an empirical rather than doctrinal matter (Stinchcombe 1991, Sawyer 2002). Sometimes individual-level explanations are ineffective or irrelevant. There are various reasons (to anticipate). (a) The presence of (say) purposive selfinterested actors in a social situation does not indicate that an explanatory model limited to such actors will be sufficient (since studying the "lower level" composition of any structure does not guarantee explanation) [Bunge 1996: Chs. 9 \& 10]. (b) "Higher-level" descriptions (more structural, more macroscopic) are sometimes better than lower-level ones_ - or the only potential explanations available (Mayhew 1980, Sawyer 2002: 23). (c) In many cases a social process, precisely because it represents "organized complexity," may have individual-level "realizations" that are too heterogeneous or complex to theorize (Simon 1962, Goldstein 1973, Stinchcombe 1991). (d) In any case, structural arguments remain possible even when individualist ones are not available (Sawyer 2002: 
220). In addition, (e) an undue focus on lower-level mechanisms can bring in causally irrelevant material (Sawyer 2003: 215). Further, (f) many social explanations do not require any particular reference to (for example) psychological states (Goldstein 1973). And (g) structural arguments do not assume or require any particular or special theory of agency or subjectivity in the first instance (Hannan 1992, Sawyer 2002). Finally, (h) in some instances a focus upon lower-level mechanisms can be an outright waste of time, if one is truly interested in explanation (Stinchcombe 1991).

\section{RECENT METHODOLOGICAL INDIVIDUALISMS}

Nonetheless in recent years doctrinal methodological individualisms have re-emerged and have become more codified and conventional (as reflected for example in Coleman 1990). A wide range of arguments in sociology focus on the aggregation of the behavior of persons or collectivities conceived as "actors," or upon the strategic interaction of putative actors. As one highly informed philosopher has pointed out, "much contemporary social science makes methodological individualism its official methodology" (Kincaid 1996: 7). (The word "implicit" might be more appropriate than "official," and the comment might especially have addressed American social theory.)

The intended scope of the newer individualistic imageries is now more expansive than with earlier exchange and behaviorist theories. In Coleman's hands, for instance, a primary objective is to develop explanations of "the macro-level of system behavior," of "institutional structure" and of "historical phenomena often large in scale" (Coleman and 
Fararo 1992: x, xvi, cf. Coleman 1990: Ch. 1). However, according to Coleman such explanation will especially focus upon the "transitions between the micro level of individual action and the macro level of system behavior" (Coleman and Fararo 1992: x), and, generally, on "mechanisms," typically individual-level ones (Hedström and Swedberg 1998).

Sometimes the newer individualistic imagery is represented in an ecumenical fashion, as only one of a set of various complementary-and-competing theoretic imageries--one that will allow sociologists to generate a distinctive set of arguments about system outcomes in various empirical domains (e.g., Coleman and Fararo 1992 and Fararo 1992). Stinchcombe (1968) presented various theoretical imageries in this way, as does Collins (1988) and Fararo (1992).

In other formulations, however, the representation of individualist theorizing is more exclusivist. In these cases there is the notion that methodologically individualist imagery is an all-purpose and in principle self-sufficient matrix for social theory, including for macrosociology. (One finds this stance in Hechter 1989, Elster 1989, Abell 1997, and Hedström and Swedberg 1998; Coleman 1990 leans in this direction.) Here one finds the "microchauvinist" claim that social scientific explanation, done properly, must reason through causal processes that reach to the presumed bottom-line of the human person, conceived as an individual and sharply-defined "actor." 
This imagery connects deeply with underlying liberal (and American) cultural models of society that notoriously dramatize purposive individual action. Many analysts of social science have detected a constitutive individualism in Anglo-American, and especially American, social science (Varenne 1984, Münch 1986, Hawthorn 1987, Levine 1995, Bunge 1996: Ch. 9, Udehn 2002, Zahle 2007:319ff, and for an especially cosmopolitan perspective, Münch 1994). As Michael Hannan has noted, in a treatment parallel to ours: “...many [sociologists] assume without reflection that sociological theories that do not direct explicit attention to natural persons are inherently flawed" (Hannan 1992: 127). A philosopher of social science has suggested that many social scientists now treat methodological individualism as a "categorical imperative," "unconditionally binding for all social scientists, because it is based on certain self-evident truths about society" (Udehn 2002: 501). A doctrinal individualism has remained compelling despite a long history of hard-hitting philosophical and substantive criticisms (in the recent period, see Lukes 1977, Mayhew 1980, Garfinkel 1981, Bhargava 1992, Hannan 1992, Kontopoulos 1993, Kincaid 1996, Bunge 1996, Fodor 1997, Sawyer 2003).

In stark contrast, in recent decades the substantive discussions of macro-social outcomes -such as long-term economic development in the historical West or in the contemporary world-have been patently "multi-level" in character, employing various structural and institutional arguments as well as individual-level ones. In the literature on AngloEuropean modernization, for example, explanatory ideas have expanded to consider broad institutional frameworks over long time periods (se e.g. Baechler et al. 1988 and Engerman 2000 for overviews). Scholars have been driven to develop various structural 
and institutional arguments- as well as individual-level ones--out of pragmatic explanatory necessity. Most of the structural hypotheses they have had to employ cannot realistically be converted into any individualist form. A whole range of useful hypotheses could not even be considered if one insisted upon employing individualist imagery in an exclusive way. Following a doctrinal individualism would have impaired the development of substantive discussion.

\section{INTELLECTUAL USES OF THE "PROTESTANT ETHIC THESIS”}

It is remarkable that Weber's narrow "Protestant Ethic Thesis" was sustained through the entire twentieth century as the canonical example of an important macro-sociological thesis. It now seems apparent that the thesis served metatheoretical and ideological missions more than substantive ones (Kalberg 1996). In the actual historical discussion of socioeconomic development in the modern world, Weber's thesis was entirely absorbed in broader analyses of institutional conditions for development.

It was absorbed in that it became part of an elaborate picture of all sorts of macro-level institutional forces producing socio-economic transformation. There are the Roman legal ideas transmitted through the Church and propelling political and organizational rationalization (Weber; Anderson 1974, Berman 1983). There is the long-term Christian demystification of nature (Weber; Eisenstadt 1999, Huff 2003), supported by a highly rationalized monasticism (Weber; Collins 1986, 1999; Werner 1988). There is the extraordinary intellectual and technological dynamism of the Medieval period, once 
conceived as dark and static (Weber; White 1978, Mokyr 1992, Landes 1998). There are the institutional sources of the states system within Christendom, and the effects of that competitive system on economic development (Weber; Strayer 1973, Wallerstein 1974, Mann 1986, Tilly 1990). Then there are all sorts of ecological factors (the physical layout of Europe, the Baltic and Atlantic economies) that weakened the controls of traditions (allowing the success of both Protestant heresy and proto-capitalist trading systems) and fostered accumulation (McNeill 1974, Jones 1981, Landes 1998, Pomeranz 2000).

In these substantive lines of thought, the Protestant Ethic thesis, as we now know it, is unrecognizable. Current discussions of European development present a broad series of institutional forces operating at a macro-sociological level, supporting some structures (the mobilized and competitive national state) and cultural models (rationalized society, moral individualism), and weakening others (feudal aristocracy, the direction of resources into the Church).

In fact, as a substantive argument, the narrow thesis was absorbed quite early, starting with Weber's own work. As Randall Collins emphasizes (1980), by the time Weber gave his lectures on "General Economic History" in 1919-1920, the Protestant Ethic thesis as we know it played a minor role. The legal and institutional changes aided by the Reformation were given great importance. But the social psychological effects of Calvinism were given a much more circumscribed place (see Weber [1923] 1950: 365ff). 
Nonetheless, the thesis survived and evolved in the last century in a completely different way, as a metatheoretical instrument rather than a substantive theory of development.

In the first half of the twentieth century, the most prominent metatheoretical use of Weber's discussion of Protestantism was as an exemplification of the conviction that society is driven by purposes and ideas, beyond raw material forces. This theme was put forward against 19th century materialist determinisms: hard-line evolutionary theories, economic variants, Marxisms, and the like. These lines of thought were intellectually powerful, and defenders of the study of modern religion, culture, moral models, and myths were on the defensive (Toulmin 1992, Gordon 1993). Weber's reputation and the Protestant Ethic thesis provided protection. The field of sociology could mobilize around the idea that values and institutions mattered (as in Parsons 1937, 1951).

In the second half of the twentieth century, less stress was placed upon the tensions between "idealist" and "materialist" explanations. Now special emphasis was placed specifically upon the volitions and choices of individual persons. It was claimed that these choices drive society and social change, almost by definition. Further, it was often argued that explanation, to be scientific, must be expressed in terms of individual humans and their choices. Weber's "salvation anxiety" idea provided a prestigious example of individualistic explanation, if with some distortion of the original text. Taking a dramatically macro-sociological issue--the rise of the modern economic system-the "thesis" provided one compelling story of how prior institutional changes, working through intra-individual processes, produced great historical change. Accordingly one 
finds a long and continuing intellectual history of sweeping claims like those of David McClelland, in The Achieving Society, suggesting that " $[\mathrm{t}]$ he Protestant Reformation might have led to earlier independence and mastery training, which led to greater $\mathrm{n}$ Achievement [need for achievement], which in turn led to the rise of modern capitalism" (McClelland 1967: 47).

An individualist rendition of Weber has strong cognitive (and normative) appeal in a liberal cultural context. Powerful economic ideas depict individual choices as (legitimate) causes of change in the economy. Powerful political ideas depict individual choices as (legitimate) drivers of political decisions. Powerful religious ideas depict individuals as making free spiritual choices that (legitimately) propel the culture. If individual choices are conceived as subject to powerful systemic influences, dominant folk theories of society may seem diminished. If the choices are conceived as having weak effects on a history that is driven by more unintentional and structural forces, the folk theories may seem violated even more. Historical and structural causation is somewhat illicit in American folk imagery, and that framing likely extends into American social science.

\section{THE BOUDON-COLEMAN DIAGRAM AND ASSOCIATED THINKING}

Within this cultural-historical context, Coleman and others, drawing on earlier work, employed the Protestant Ethic thesis in an influential recent tutorial for sociological explanation (Coleman 1986a, 1986b, 1987, 1990). Gudmund Hernes has made similar 
use of the work (1989, see also 1976), as did Hans Zetterberg earlier (1965, also 1993). Raymond Boudon has made related arguments (e.g. Boudon 1981), as have R. Wippler and S. Lindenberg (Wippler 1978, Wippler and Lindenberg 1987), and Hartmut Esser (1994). In each case, an individualistic explanatory scheme is offered, and Weber's more structural and institutional arguments are set aside. Numerous textbook treatments have followed suit.

Figure 2 shows the way in which the Protestant Ethic thesis is presented by Coleman, following many predecessors. We insert the labels of types of "mechanisms" suggested by Hedström and Swedberg, who generalize Coleman's treatment (Hedström and Swedberg 1998: 21-22; cf. Esser 1994). The figure shows a very simple explanatory structure. Causal relations between historical and institutional structures occur primarily or exclusively through micro-processes: i.e., through similar situational effects on a large number of individuals, who then generate new lines of action, together transforming society. Coleman et al. do not use the scheme to grapple with substantive arguments about the rise of the modern economy, or with substantive treatments of various effects of Protestantism. Instead they are advocating a certain style of explanation, and arguing (to varying degrees) that it should have something close to monopoly status within social science. 
Coleman's initial discussions accompanying his schema indicated that causal effects can in fact occur at multiple levels of analysis (1986a, 1986b, 1987). Coleman gave examples of hypothesized collective effects, referring to work by Hannan and Freeman (1986) on organizational change and by Skocpol and Orloff (1986) on welfare states (Coleman 1986b: 355ff). Coleman raised some questions about these collective-level arguments but he did not rule them out. Instead Coleman indicated that he was primarily interested in developing a better "theory of transitions" between the level of behavior of individual actors and the level of social system behavior (Coleman and Fararo 1992: ix; cf. Coleman 1987).

At other points, however, Coleman's treatment slides into a doctrinal individualism. For instance, in his fuller (1990) treatment, Coleman dispenses with any exclusively systemlevel interconnections (i.e., the macro-to-macro arrow). The examples of possible collective effects are dropped from the account. Here Coleman is disposed to claim that "the central theoretical problem in sociology is the transition from the level of the individual to a macro level" (1986b: 347). He suggests in addition that macro-level propositions are temporary stand-ins for individual-level explanations (1990: 20).

With these latter arguments the "macro-micro-macro" sketch became easily interpretable by others as an all-purpose form of explanation, and Coleman became associated with a doctrinal individualism not reflected in his own empirical research. Hedström and Swedberg (1998), for instance, seem to present the schema as an all-purpose one in just 
this way. Wippler and Lindenberg have made similar arguments (e.g., Wippler and Lindenberg 1987). Here is Hedström and Swedberg's treatment:

... proper explanations of change and variation at the macro level entails showing how macro states at one point in time influence the behavior of individual actors, and how these actions generate new macro states at a later time. That is, instead of analyzing relationships between phenomena exclusively on the macro level, one should always try to establish how macro-level events or conditions affect the individual (Step 1), how the individual assimilates the impact of these macro-level events (Step 2), and how a number of individuals, through their actions and interactions, generate macro-level outcomes (Step 3) (Hedström and Swedberg 1998: 21-22, emphases added).

[They add a footnote that says:] The logic of Coleman's argument also suggests that any kind of continuous social action can be conceptualized as a long chain of

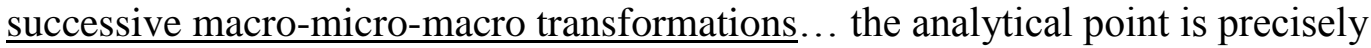
to explain this cumulative social action of a large number of macro-micro-macro transitions (ibid. p. 22, emphases added).

This conceptualization reflects the reinvigorated doctrinal individualism that we critically highlight.

\section{MULTIPLE LEVELS OF ANALYSIS IN SOCIOLOGICAL EXPLANATION}


If one insists upon individualist formulations, wide ranges of social processes will not be considered for possible hypotheses. To make this point about the limitations of methodological individualism, we reconstruct the substantive discussion of Protestantism and capitalism in an explicitly multi-level fashion. We discuss individual-level linkages. But beyond them we note distinct sets of causal processes working through socialorganizational arrangements, and then processes occurring at a very macro-sociological, or institutional, level.

\section{$\underline{\text { Levels of analysis }}$}

Our understanding is that "levels of analysis" in scientific explanation refer to sets of causal processes, each representing different degrees of organizational complexity (hence the idiom of "levels of organization" and "levels of complexity"). The issue is discussed by Simon (1962) and Kontopoulos (1993) for the social sciences, by Gell-Mann (1994) and Wilson (1998) for the physical sciences, and by Bunge (1996), Sawyer (2002), and Thomson (2003: Ch. 8) in recent philosophical commentary. Philosophers and scientists refer to quantum-level processes, atomic-level ones, molecular-level ones, cellular ones, and so on through ecological processes and beyond--a hierarchy of lower-to-higher degrees of organization. "Higher-level" processes are currently stable "emergent" configurations of lower-level ones; these configurations then themselves have causal powers. (See Thomson 2003: Ch. 8 for a standard philosophical discussion; also Bunge 1996: Ch. 9 \& 10.) 
Herbert Simon referred to a continuation of such levels into the "architecture of complexity" of the social world (Simon 1962): a hierarchy of levels of organization ranging from social-psychological processes and "elementary social behavior" (Homans' term, 1961) through various social-organizational processes, to the culturalorganizational complexes called institutions. This social architecture is presumably bounded on the "lower" side by the psychological and biological processes seen as subsocial ones; on the other ("higher") side, beyond institutions and culture, it is bounded by the intellectually-undifferentiated complexity known as "history."

In the multi-level exposition here we distinguish for expository purposes between three different levels of causal processes in sociology: we label them individual, socialorganizational, and institutional ones. ${ }^{1}$ For example, when scholars think about economic development they consider individual-level processes, such as the possibility that societies may develop more rapidly because their individual persons are educated and more productive. They also consider social-organizational ones, such as Wallerstein's ideas about how particular trade dependencies may affect development opportunities (Wallerstein 1974). Other potentially relevant processes may be more institutional in character, as when expanded education legitimates and then fosters technical and social rationalization, through various mechanisms, sometimes eventuating in economic development (Meyer 1977). 
Furthermore, there are the possibly consequential interactions among processes operating at different levels. For instance, the individual effect of education may depend on institutional rules giving credentialing advantages to educated persons (Meyer 1977, Collins 1979). The effects of schooling and other socialization efforts are likely to be weak in social contexts that do not support or legitimate the new values. Instruction in knowledge and values is likely to be more effective if the possession of the new knowledge or values is rewarded by, and required in, valued roles in society. In any case, the causally-operative levels (and specific linkages) must be decided via substantive and empirical adjudication, not by any metatheoretical pre-commitments.

\section{Explanation in terms of individual and elementary social processes}

In their "individual level" investigations, social scientists typically refer to the following processes:

-- strictly individual-level, sub-social, processes, i.e., those considered to be primarily biological and psychological in origin and organization;

-- social-psychological processes (processes in which both intrapsychic and social mechanisms are inextricably engaged, such as in personality formation);

-- "elementary social behavior" in the sense of Homans (1961) (e.g., interaction in small groups), or Schelling (e.g., in his "tipping” models of residential segregation, invoking simple social processes involving very little social organization [Schelling 1971]); 
-- organizationally rudimentary exchange relations, simple group dynamics, "collective behavior" (e.g., crowd dynamics), and "simple" forms of strategic interaction (such as those captured by game theory). ${ }^{2}$

In Weber's Protestant Ethic there were two main individual-level arguments. The "salvation anxiety" argument about Calvinism - the idea that predestination produced uncertainty and compelled self-discipline and hard work--is the individual-level proposition that has been especially attractive to metatheoretical users of Weber. We must point out that this idea has not fared well in substantive discussion. In offering the idea Weber relied more on rather unconstrained "verstehen" than evidence: as Gianfranco Poggi puts it, Weber used texts of Puritan divines (and Benjamin Franklin) "to characterize the content of the spirit of capitalism" in order to "support... his own imaginative reconstruction of the 'mind set' of the early capitalist entrepreneurs" (Poggi 1983: 47; cf. Parkin 1982: 45 and Ch. 2, MacKinnon 1993, Benedict 1993, Hamilton 2000). Contemporary empirical social science is critical of the kind of psychology involved in the "salvation anxiety" proposition. It turns out that fear is often a poor motivator of complex behavior (e.g., ceasing to smoke, driving safely, avoiding drugs), and it is difficult to imagine that people can be frightened into the kind of long-run behavior encouraged in capitalism.

In his own work, Weber emphasized a second more general individual-level dynamic. "Psychological impulses originating in religious belief...[give] direction to the individual's everyday way of life and [prompt] him to adhere to it" (Weber in Bendix 
1960: 63-64). Protestant sects, especially Calvinism (he thought) extended a more "rational mode of life," an ascetic mode of life, outside of monastic circles--in effect, bringing religious discipline to the masses (Weber [1923] 1950: 365; Collins 1980 for commentary; Gorski 2003 for extension of the analysis to the political realm). Religious strictures encouraged the "rationalization of the conduct of life in general" (Weber, ibid.: 354). Over time, more individuals became responsive to economic discipline and economic motivation.

This second more general formulation ended up as the main individual-level component in Weber's much broader explanatory framework (again, Collins 1980). The "world historical transformation"--the development of economic rationalism--"was not the product of Puritanism; rather, Puritanism was a late development that reinforced tendencies that had distinguished European society for a long time past" (Bendix 1960: 71-72).

The point is that Weber's individual-level arguments were highly contextualized--in contrast to the impression given by the doctrinal individualist sketches. More recent empirical research has taken the same direction. Researchers are increasingly aware that each part of the causal sequence of Figure 1 requires special conditions. Without strong institutionalized support for transformed individual outcomes: (a) The socializing effects of Protestantism on individual attitudes are not likely to be strong. (b) Whatever attitudes may be changed are unlikely to be stable over decades. Personality characteristics are known to be unstable over long periods. (c) Any changed attitudes are unlikely to lead to 
changed behavior, absent strongly supportive conditions. Changed behavior in the workplace is known to require strong structural support. (d) Finally, changed individual attitudes or behavior are unlikely to aggregate into shifts in the institutional structure of society. Weber himself stressed again and again that strong desires for profit characterize many societies without producing anything like capitalism (e.g., Weber [1920] 1996: $17 f f)$.

This necessary contextualization presents a problem for those who would privilege individual-level explanations of macro-social change. For a sequence like that pictured in Figure 2 to be credible, it must be embedded in a society that legitimates Protestant beliefs, that continually reinforces them in individuals, that facilitates their implementation in capitalist action, and that validates capitalist action (formerly stigmatized, as in most societies) as producing the collective good. But if all this supportive social structure is in place, one must consider whether it has effects of its own, quite over and above any effects on individual motives. And if all this supportive structure exists for capitalist activity, why would this activity depend on the private fears and hopes of individuals?

There is no reason to resist individual-level (and "elementary" social) explanation per se - macrochauvinisms are as arbitrary as micro ones. For example, there is no reason to resist, for the topic we are analyzing, ideas about the "production of capitalistic individuals" (Weber [1923] 1950: 368-369). David Landes's recent rendition of an individual-level hypothesis seems entirely plausible: that Protestantism eventually 
"encouraged the appearance in numbers of a personality type that had been exceptional and adventitious before," a "new kind of businessman" that was an important ingredient in the expansion of the new manufacturing enterprises (Landes 1998: 178, 175). Our point is rather to criticize the exclusive insistence upon individual-level formulations. Individual-level explanations are a necessary but not sufficient component of social science.

\section{Explanation in terms of social-organizational processes}

Sociologists seem to distinguish two "structural" levels of analysis above the individual (including elementary social) level. One is social-organizational, the other more institutional. $^{3}$

By social-organizational processes we refer to the causal influences attributed to (for example) hierarchic, network, market, and ecological formations. In each case, specific structural features are the properties of interest: as for instance in Simmel's idea that triadic structures generate distinctive dynamics wherever found. In contemporary work, exemplars are Granovetter's ideas about effects of weak versus strong network ties (1973), Burt's ideas about effects of "structural holes" (1982), Harrison White's ideas about dynamics of "vacancy chains" (1970, cf. White 1992), and ecological ideas emphasizing the effects of properties of competitive niches upon organizational survival (Hannan and Freeman 1989). 
Sociologists also invoke a number of "emergent" social-organizational properties that have a more cultural character. The idea that group values or prestige patterns are such properties is core to sociology. So are the ideas about group emotional dynamics and interaction rituals (Collins 2004), and ideas about organizational and professional cultures. So is the idea that highly "typified" social positions arise in social life (roles).

Weber's main social-organizational idea about Protestantism, as reconstructed by Poggi, has to do with the formation of a new collective actor (Poggi 1983). In Poggi's interpretation, Protestantism facilitated the transformation of a pre-existing collective actor--the urban commercial estate--into the legitimated burgher class of entrepreneurs. Protestantism enhanced the class solidarity among Protestant burghers, by providing a religiously-based class morale. In addition, rising commercial classes embraced Protestantism for purposes of political and economic legitimation (Bendix 1960: Ch. 3, Parkin 1982: 60-62). Networks of the new collective actors could expand, facilitated by common ideology and the trust generated by shared community (ibid.; cf. Mann 1986).

In a more structural imagery, the capitalist is produced less by the inner motives of some individuals than by an evolving religious and political structure that defines a new role or collective actor. The new structures give prestige and legitimacy to the role, and set it in effective relation to other structures, including the state, the religious system, property ownership, and the family system. Quite apart from any motivational effects, the Reformation certainly modified roles and organizational structures throughout society. It weakened the legitimacy of many important roles, and dramatically strengthened others. 
In the religious arena, the authority of state elites was greatly expanded, and the old roles undercut-priests and bishops were subordinated, and the authority of the cathedral and monastery and papacy destroyed. The religious autonomy of the individual, and of the church as an association of individuals, was enhanced. Politically, landowners and aristocrats were weakened, and the rationalized state greatly empowered. Economically the old roles of the pariah bankers and merchants were undermined, along with the whole complex of landowner-serf relations. The authority and legitimacy of free individuals functioning in markets were obviously greatly strengthened.

Structural explanations, in other words, give accounts of how changed distributions of social values and opportunities occur--in this case, we would add, supported by fairly dramatic religious changes. Much less causation is located in individual personality or actorhood, and structural arguments do not typically rely upon strong (and empirically questionable) assumptions about the competence, coherence, and boundedness of persons. People can often be assumed simply to adapt to (and incorporate) the changed values and opportunities of their environments. It is one thing to be a capitalist if that implies the social role of pariah or alien or thief--perhaps some very distinctive values and orientations are necessary, requiring much socialization (religious or otherwise). It is quite another thing to be admired as a capitalist carrier of progress, and quite routine motives may suffice to encourage individuals to want to be recognized as successful. One does not need to assume or assert very much about values or personality to understand that young persons in the 1990s might have seen investment banking as a good career to pursue. 


\section{$\underline{\text { Explanation in terms of institutional processes }}$}

In American sociology, structures are often envisioned mostly as networks, with limited cultural meaning and with very few supra-individual properties or consequences of their own. A recent example is provided by Padgett and McLean (2006), who say that they represent social context by “multiple-network architectures" (p. 1468). People are treated as "cross-domain composites of roles" (p. 1469). This kind of reasoning has substantial utility (including mathematical tractability and wide-ranging empirical applications), but it does not fully capture the actual imagery about roles used in substantive macrosociological explanation. For instance, the destruction of the "priest," and of the magical values attached to formerly stigmatized roles of the entrepreneur or the usurer, seem very imperfectly captured by any purely formal network imagery. These roles embody dramatic cultural meanings — grand social models and ideologies extending across time and space. They involve cosmologies as well: fundamental metaphysical claims about the nature of humans, the physical world, and the moral world.

Historically, sociology has pulled together conceptions of phenomena at this level of analysis using the concept "institution" (Berger and Luckmann 1967, Buckley 1967, Eisenstadt 1968a). Institutions have organizational components--structures of authority and responsibility, often integrated in something like control systems. They also have cultural dimensions--generalized models formulating and justifying rules, routinely built up into systems of thought and analysis (legal models, political models, religious models, 
knowledge systems, professional discourses, cosmologies). Typical instances of institutional structures such as the Catholic Church, national state, the monetary economy, a constitutional legal system, the limited-liability corporation, scientific academies, and the research university exemplify both organizational and cultural dimensions.

It is quite apparent that distinctive causal processes operate at the institutional level, beyond the levels discussed previously. For instance, substantive treatments of the Reformation (by Weber and others) routinely include-even feature--institutional-level arguments. Stepping back, we can see that scholars have called particular attention to the following institutional-level processes (cf. Eisenstadt's important early reviews [Eisenstadt 1965, 1968b] and Gorski's recent complementary discussion [Gorski 2005]).

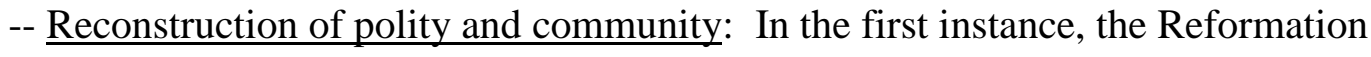
obviously weakened the roles and ideas linking society in a liturgical manner, via the Church and a nominally hierarchical social order (Eisenstadt ibid., Walzer 1965, Zaret 1989). It led to the collapse of the ideal of imperial unity as well (McNeill 1963). Instead the eventual Reformation settlements ended up strengthening new ideas of corporate territorial "societies" independent of the Church (ibid.; Parsons 1977). Moreover, the main institutional innovation of Protestantism- the sect-represented a new model of polity and community. ${ }^{4}$ This model constituted individuals as empowered and responsible agents, in principle responsible for bridging the gap between spiritual ideals and mundane realities. People were pressured to throw off what Marx called "the idiocy 
of rural life" and to enact an entirely new identity, eventually producing the "cult of individualism" (Durkheim [1898] 1969) that we now naturalize.

-- Legitimating and reconstructing economic activity: By investing economizing with moral significance, Protestant ideology contributed to the collective legitimation of practical economic activity, and of profit and wealth. This line of argument was at the core of Weber's Protestant Ethic, but commentators have focused upon the more individualistic formulations. Private gain became a public good in the new cultural models. This change was a striking departure from the ideological stigmatization of commerce typical in agrarian societies and pronounced in Catholic natural law doctrines. Ideas of just price and just wage, for example, had left economic activity in a state of “intellectual, moral, and legal chaos” (Lüthy 1968: 106). Protestant reform groups directly contributed to reformulations of ideas of covenant, contract, and natural law. Calvin himself worked on ideas for rationalizing capital and interest accounts (ibid.: 107). Banking was re-envisioned as part of an autonomous economic sphere, governed by its own distinctive economic calculus. Restrictions on entrepreneurs and corporations were eased. Eisenstadt talks about a general "incorporation of Protestant premises into law" in England, Scandinavia, Netherlands, and (later) the U.S., making eventually for more "flexible," "open," and "autonomous" institutions (Eisenstadt 1968b: 12). CounterReformation zones, in contrast, tended to stifle the economic developments of the time (Trevor-Roper 1967, Lüthy 1968). 
-- Legitimating the national state: The attack on the Church provided charters for the national state as the primary legitimate polity, and subsequently for proto-national development efforts (Parsons 1977, Mann 1986: 467ff, Wuthnow 1989). In the first instance, Calvinism appears to have provided new models of social discipline and executive administration, central in national state-building efforts in some zones of Europe (e.g., in Netherlands and Prussia) [Gorski 2003].

-- Restructuring collective action: Protestant sects made new voluntarist organizational forms possible. The very idea of sect members running their own congregations allowed for ongoing experiments with new models of organized action (Thompson 1963, Walzer 1965). People no longer required clans or guilds to act collectively. In addition, Protestant cultural models gave concrete legitimacy to a wide range of collective projects for intendedly rational action in a mundane world, not just economic ones. Protestant ideas "[opened] up the world as a thoroughly objectified, profaned, manipulable field for purposeful action" (Poggi 1983: 70, paraphrasing Weber), while desacralizing older forms of authority and related traditions (Walzer 1965). Ideas about the potential for and obligation of social progress intensified. ("It was the Reformation that re-established the ethical rigorism and instrumental activism of the Old Testament" [Münch 1994: 183].) Ideas that this progress could occur in part through the action of a society of ordinary persons became far more prominent--after all, Protestantism greatly expanded the number of imagined empowered souls in the world. But notions of these kinds were put in place not by role or dispositional evolution, but by central authorities carrying broad theoretical discourses (e.g., the English, French, and American revolutionaries). 
-- Legitimating science: The institutionalization of religious pluralism in Europe, after the settlements of the Religious Wars, indirectly contributed to the conventionalization of intellectual pluralism (McNeill 1963, Zaret 1989). In so doing the Reformation promoted "the [ideological] skepticism and refusal of authority that is at the heart of the scientific endeavor" (Landes 1998: 179). Recent work has backed Weber's tentative conclusion that while "scientific progress and Protestantism must not at all be unquestioningly identified," Protestantism helped to "[place] science in the service of technology and economics" (Weber [1923] 1950: 368; cf. Mann 1986: 471 and Landes 1998: 178ff). Hence Protestantism not only encouraged "high science" (Mann, ibid.), but promoted the gradual rise of science as a central modern institution relevant for every collective purpose (Drori et al. 2003).

The Reformation clearly involved institutional changes in dominant models of individual and society. The changes were widespread across societal sectors; they were not simply economic in consequence. And as institutional changes they had long histories in Western development--long preceding and long following the Reformation itself.

\section{Multi-level Analysis}

The point of the above section was to call attention to obvious lines of likely distinctive causal influence. We epitomize the discussion in Figure 3, which provides a multi-level alternative to Figure 2. We show causal pathways operating at several levels of analysis, 
some individual-level, others social-organizational, and still others institutional. If one reifies the Boudon-Coleman diagram (Figure 2) — and the way of thinking associated with it--one is likely to fixate on possible causal processes such as the "Protestant Ethic thesis." One might not seriously seek out causal possibilities such as the socialorganizational and institutional ones we have discussed (cf. Garfinkel 1981: 164ff for a clear rendition of this point about limitation of inquiry). Yet, as we have seen, discussion of the possible relations of Protestantism and capitalism would remain entirely superficial unless one does consider them.

\section{<FIGURE 3 ABOUT HERE>}

\section{THE CONFLATION OF EXPLANATION AND MICROFOUNDATIONS}

Doctrinal individualists might persist in arguing that one should seek to convert any of the arguments of Figure 3 into the schema of Figure 2. Hedström and Swedberg (1998) seem to make this argument, in the passage quoted earlier. The idea that structural arguments are at best explanation sketches, to be resolved into and replaced by more adequate individual-level explanations, is now relatively commonplace in sociological theory. This idea actually conflates a number of separate issues. First, there is the requirement of adducing specific causal processes if one purports to offer a causal explanation. Second, there is the necessity of being able to illustrate micro-instantiations of any process (i.e., examples of the constituent people and activities involved). Third, there is the alleged necessity of formulating arguments exclusively in terms of micro- 
processes. Put in a phrase, the doctrinal individualists conflate issues of explanation with issues of microfoundations. (See Kincaid 1996: Ch. 5 for an extended philosophical development of this criticism; also Bhargava 1992 and Sawyer 2002.)

The distinction between microfoundations and explanation has great import across the sciences. Consider current theories of psychological depression. As is well known, it is now thought that neurotransmitter balances are important chemical-level foundations of mental health. Yet psychologists obviously consider multiple possible etiologies-i.e., multiple explanations - of depression. The etiologies are not limited to an invocation of neurotransmitter imbalance. Instead, the explanatory relevance attributed to (say) serotonin will vary. Perhaps some depressions can be attributed solely to geneticallybased or ontogenetic serotonin imbalance. But in other proposed etiologies, neurotransmitters may be envisioned only as the carrying or mediating foundational "wetware"-part of the "mechanism" structure--without having explanatory centrality. For instance, it has been proposed that some depressive syndromes are adaptive responses to trauma among less-"resilient" individuals (put aside the potential tautology here) [Kessler 1997]. It has been proposed that women may inhabit more depressogenic social networks than men (Kessler and McLeod 1984). It has been proposed that some depressive syndromes are culturally-scripted personality styles (an allegation about Central Europe, for instance [e.g., Townsend 1978, Kurzweil 1989]). These etiologies invoke different levels of causation. In each of these putative etiologies - only a few caricatured here--serotonin (say) will be present and operative, but playing different causal roles, and having varying explanatory import. 
The example of depression is representative of countless others across the sciences, wherein microfoundations must be distinguished from etiologies, and hence from explanation - as opposed to being conflated with them. The analogue in sociology is the following. The "microfoundations" of social-organizational and institutional causal pathways are not equivalent to individual-level causal arguments. For example, the micro-composition of a truly collective-institutional process is not equivalent to one of Coleman's macro-micro-macro explanations.

To illustrate this point for sociology, one can consider the different "micro-samples" that make up different causal processes. A micro-sample refers to the constituent people and activities isolated in a specific setting and time (we adapt language from Collins 1981 and 1988). The micro-samples of any social process, suggests Collins, can be imagined as "film-strips"-that is, what specific scenes might one film in an attempt to capture some imagined social process? Thinking this way it is obvious that the scenes (people and activities) that one would film in order to capture an institutional process are different from what one would film to capture a social-organizational process or--most relevant here--an individual-level one. Any of the possible processes connecting Protestantism and capitalism at the different levels could be filmed-with some thought and creativity, of course--and in that sense one would capture "micro-samples" in time and space. But the scenes, players, and activities would be quite different at each level of analysis. 
The filmstrips (micro-samples) of an hypothesized individual-level process might in fact capture (for example) some version of Coleman's macro-micro-macro Protestant Ethic sequence-say, Landes's (1998) version mentioned earlier. (Different religion, different socialization, different aggregated behaviors reshaping community.) But the filmstrips of an institutional-level process-its micro-samples--would not capture a Protestant Ethic process or any other process at the level of the person seen as an individual actor aggregating with other individual actors, or interacting with another in a simple strategic game. For instance, if one considers Lüthy's (1968) account of reformulations of banking laws-an institutional story--the samples would be drawn from legal guilds and court ministries, featuring legal and religious professionals enacting highly institutionalized roles. One would be sampling how Protestant theory modified the collectively dominant model of society. Priests and lawyers and state elites, operating as carriers of the changed model, worked to change various rules of the social game. They worked to legitimate usury, for instance. Eventually they begin to affect the thinking of princes' chief lawyers. And eventually rich people become more likely to use their money as capital investment, rather than using it to buy status and protection.

Of course collective processes are produced and reproduced by persons' behaviors (the "ontological truism"). But the "microfoundations" of many collective processes do not involve a mass of similar individuals, operating as choosing actors, affected by a situation, taking new actions, and changing society via some aggregation or assembly. One would not be able to work a truly collective process into such a framework: the micro-realizations of institutional processes are likely to be multiple and heterogeneous- 
since institutions are chronically reproduced complexes of rules, roles, routines, and meanings. ${ }^{5}$ The complex called capitalism, for example, is obviously made up of a host of these.

Put another way: Individual-level causal pathways capture effects produced by relatively unorganized people. The causality, so to speak, is generated by their sub-social or elementary social characteristics. In contrast, more structural imageries capture causation generated by more and more complexly organized activities. The concept of "emergence" in social science stems from the idea of chronically reproduced and consequential configurations of heterogeneous behaviors. In social-organizational imageries, for example, the featured causal influences might be those emanating from (say) relatively durably-organized networks of social roles, or collective cultural and religious commitments. These patterns will have distinct micro-instantiations, having to do with (for instance) the opportunities or communications available to people (or other units). But the causality lies with the effects of the role networks themselves, not with variations in the unit-level properties.

Similarly, in more institutional imagery, the featured causal influences are those generated by broad complexes of organization and meaning. The micro-instantiations might have to do with (for instance) complementary sets of role enactments, or with enactments of broad ideological scripts. But the causality emerges from the complex organization of roles, routines, and meanings that we call institutional structure--and not from variations in role enactments or in the individuals involved. 
The recent emphasis on "mechanisms," we must add, has obscured the above distinctions rather than illuminated them. It is not only that the term is used in all sorts of different ways (Mahoney 2001 finds 24 definitions among 21 authors; Gerring 2007 finds 9 distinct uses). The problem is deeper than that. First, the discourse about mechanisms conflates the idea of causal process, in general-a causal pathway or "chain"--with the idea of the lower (or lowest-relevant-level) causal processes within a multi-level system. Second, some analysts conflate microfoundations with causality in general (Hedström and Swedberg 1998 seem to do this, as does Little in his recent philosophical review [2007: 358]).

The conflations ensure the elision of the core analytical distinction illustrated by the substantive portion of this article. That distinction, to summarize, is the following. Two macro-properties can be connected via a micro-level causal pathway, as the BoudonColeman diagram envisions. But two macro-properties may also be connected via distinct macro-level causal pathways — or distinct meso-pathways — as our outline of Weber's topic has shown (and as Figure 3 illustrates). In the latter case, one can seek out microfoundations if it is analytically useful to do so-Stinchcombe's (1991) original point. The recent literature on mechanisms misses this fundamental distinction, and hence avoids the real theoretical task of sorting out the multiple levels of analysis involved in sociological explanation.

\section{CONCLUDING REFLECTIONS}


We have emphasized the intellectual costs of assigning privileged status to individualist explanation, using interpretations of Weber's Protestant Ethic as our focus. Any levels essentialism, micro or macro, will distort and impoverish social science.

In the contemporary period, microchauvinism seems to have an enduring power over the social scientific imagination, promising a great simplification that might finally lead to a pure social science. In contrast, older "macrochauvinisms" have dissolved, remaining only in residualized forms in some Continental circles. (See Varenne 1984 and Münch 1986 for related discussion of patterns of social theory and Zahle 2007: 319 for relevant citations.) In the physical sciences, multi-level theorizing has developed robustly in contemporary period, challenging and slowly displacing doctrinal "atomisms"—-doctrinal "holisms" being displaced much earlier (Bunge 2000: 384; also Gell-Mann 1994 and Wilson 1998). From a scientific standpoint, pure atomisms and pure holisms are fictions (Bunge 2000: 396). All the sciences must attend both to composition and to emergent systemic properties, and only some of the latter result from aggregation (Bunge 1996: 256 and Chs. $9 \&$ 10, Thomson 2003: Ch. 8).

It is worth reflecting, then, why social scientists in the modern period recurrently return, often with a good deal of passion and even moralism, to micro-reductionist themes. Arguably the extraordinary focus upon individual-level explanation in social theory is part of the ideological system of modernity, tied to the romance of human agency and intentionality (Sawyer 2003: 221ff), and thus linked to normative commitments in social 
policy (e.g., Bunge 1996: Ch. 9). (For parallel analyses of the relation of German social theory to the German polity and society, see Münch 2001.) This ideological system socially constructs a powerful taste for "rock bottom" accounts (Watkins' phrase, 1957). Many social analysts are content only when they can suggest such an account. They want to focus primarily upon real or imagined individual motives, and some are even happy with highly fanciful "as if" psychological pictures (as in some economic theory). These social scientists are of course aware of institutions and culture to varying degrees, but their inclination is to neglect such forces in their professional social scientific capacities. The neglect is sometimes justified with the idea that such forces cannot be theorized, or with the idea that individual-level analyses will implicitly capture them. Recently one even finds the idea that sociology might best forego explanation altogether, and focus instead on isolating and describing "mechanisms" (Mayntz 2003 and Gerring 2007 discuss this recent development; Elster 1989 and Tilly 2001 provide prestigious examples of the drift away from explanation).

There is an underlying tension within modernity's ideological system between its individualist romance and its scientific project (or pretense). The latter leads necessarily toward biological, ecological, and cultural determinism, and hence to displacement of action theories. But a society that stresses decisions and decision-based "actions"- by persons, organizations or states-will tend to support simplified and reduced models, whatever violence to reality such models may do (Kahneman, Slovic, and Tversky 1982; Brunsson 1985). Such models are in fact found wherever dramas centered on empowered actors are central-today the world of interstate relations, of interorganizational relations, 
the market world of relations among individuals seen as actors, and of course the "spiritual" world. An underlying imagery of plebiscites and markets, of voting and buying, looms large in contemporary social science — but it can be a procrustean one.

Contemporary globalization and liberalization have weakened notions of states or communities as primordial collective actors, and have driven the "cult of the individual" (Durkheim [1898] 1969) to heights Durkheim could never have envisioned. Now there are strong folk and professional visions of a whole world of equal, free, educated individuals making all the choices that drive a global economy, polity, society, and cultural system. The individual, now, is the one certain ontological element left in social life. It is no wonder then that social science, never far removed from broad folk and policy models, reifies these epochal institutional shifts.

The most rapidly developing industries in the contemporary world are those that prop up the individual as actor-masses of educators, therapists, consultants, and professional advisors. Similarly expanded industries service the other more derivative actors of the modern system-the rationalized organization, the expanded service-oriented state. So exaggerated intellectual individualisms become possible because of extraordinarily elaborated institutional structures, ones that such intellectual individualisms would downplay or disregard. 
FIGURE 1

\section{"BOUDON-COLEMAN DIAGRAM"}

(After Coleman 1986a and 1986b, and Hedström and Swedberg 1998)

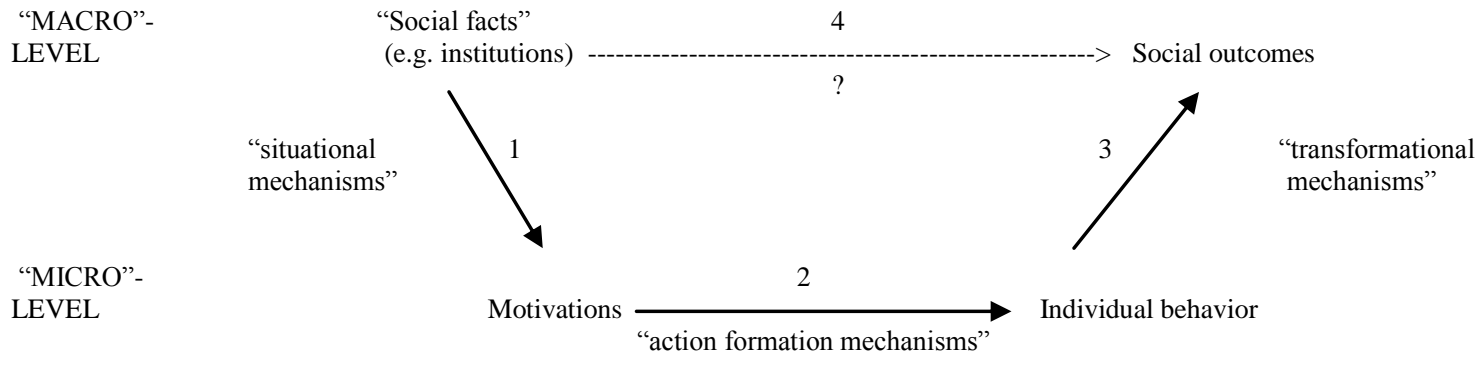




\section{FIGURE 2}

\section{TYPICAL RECONSTRUCTION OF WEBER'S “PROTESTANT ETHIC THESIS”}

(after Coleman 1986a and 1986b, and Hedström and Swedberg 1998)

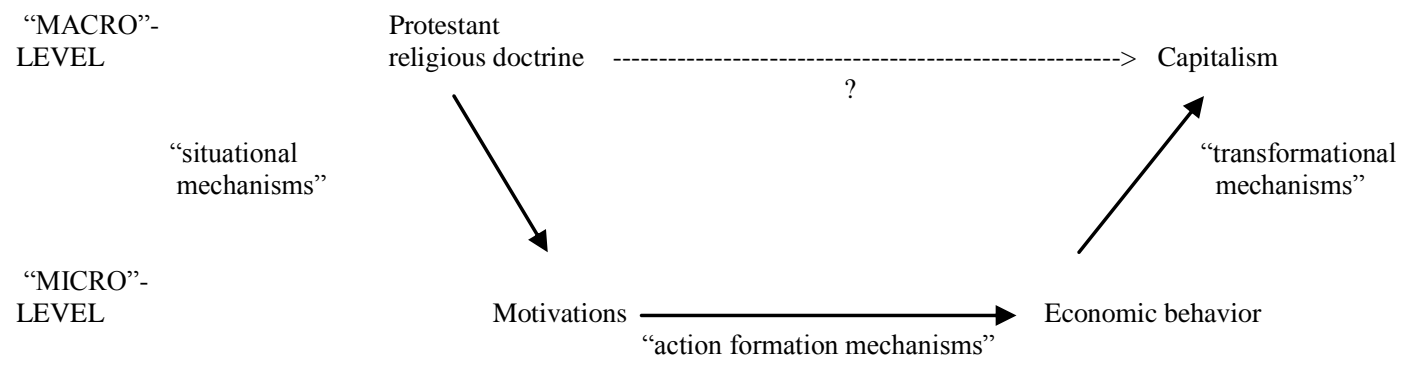


FIGURE 3

\section{POSSIBLE PATHWAYS LINKING PROTESTANTISM \& CAPITALISM AT DIFFERENT LEVELS OF ANALYSIS}

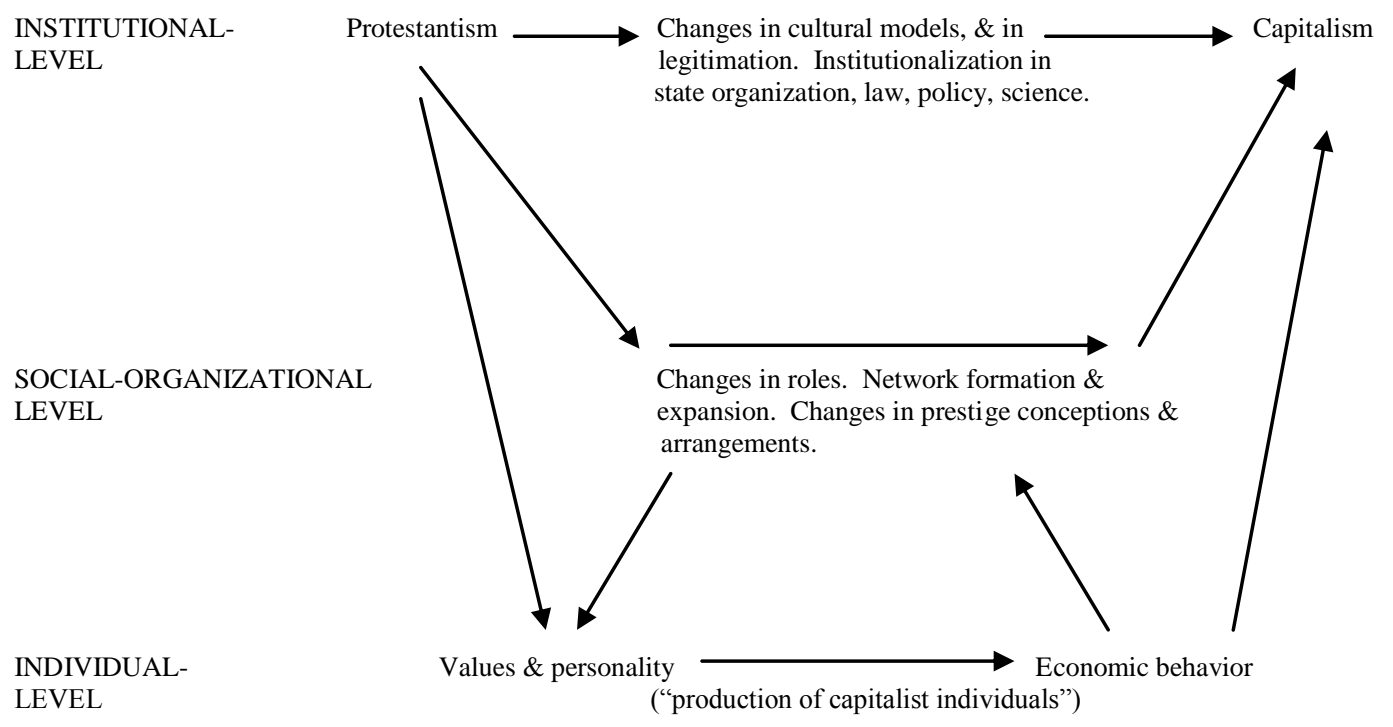




\section{REFERENCES}

Abell, Peter. 1997. “Homo Sociologicus: Do We Need Him/Her?” Pp. 229-234 in

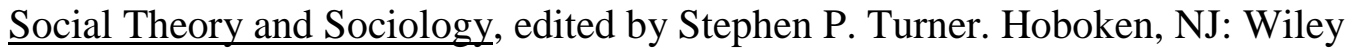
Blackwell.

Alexander, Jeffrey C., and Bernhard Giesen. 1987. "From Reduction to Linkage: The Long View of the Micro-Macro link.” Pp. 1-44 of The Micro-Macro Link, edited by J.C. Alexander et al. Berkeley: University of California Press.

Anderson, Perry. 1974. Lineages of the Absolutist State. London: New Left Books. Baechler, Jean, et al. 1988. Europe and the Rise of Capitalism, edited by Jean Baechler, John A. Hall, and Michael Mann. Oxford: Basil Blackwell.

Bendix, Reinhard. 1960. Max Weber: An Intellectual Portrait. Garden City, NY: Anchor.

Benedict, Philip. 1993. “The Historiography of Continental Calvinism.” Pp. 305-326 in Weber's Protestant Ethic, edited by Hartmut Lehmann and Guenther Roth.

Cambridge: Cambridge University Press.

Berger, Peter L., and Thomas Luckmann. 1967. The Social Construction of Reality. Garden City, NY: Anchor.

Berman, Harold J. 1983. Law and Revolution: The Formation of the Western Legal Tradition. Cambridge: Harvard University Press.

Bhargava, Rajeev. 1992. Individualism in Social Science. New York: Oxford University Press.

Blau, P. M. 1960. "Structural Effects.” American Sociological Review 25: 178-193. 
-----. 1974. "Parameters of Social Structure.” American Sociological Review 39: 615635.

Boudon, Raymond. 1981. The Logic of Social Action. London: Routledge and Kegan Paul.

Brunsson, Nils. 1985. The Irrational Organization. Chichester: Wiley.

Buckley, Walter. 1967. Sociology and Modern Systems Theory. Englewood Cliffs, NJ: Prentice Hall.

Bunge, Mario. 1996. Finding Philosophy in Social Science. New Haven: Yale University Press.

-----. 2000. “Ten Modes of Individualism—None of Which Works—And Their Alternatives." Philosophy of the Social Sciences. 30/3: 384-406.

Burt, Ronald. 1982. Toward a Structural Theory of Action: Network Models of Social Structure, Perception, and Action. New York: Academic Press.

Coleman, James S. 1986a. "Social Theory, Social Research, and a Theory of Action." American Journal of Sociology 91: 1309-1335.

-----. 1986b. "Micro Foundations and Macrosocial Theory.” Pp. 345-363 in Approaches to Social Theory, edited by Siegwart Lindenberg, James S. Coleman, and Stefan Nowak. New York: Russell Sage Foundation.

-----. 1987. "Microfoundations and Macrosocial Behavior." Pp. 153-173 in The Micro-Macro Link, edited by Jeffrey C. Alexander, Bernhard Giesen, Richard Münch, and Neil J. Smelser. Berkeley: University of California Press.

-----. 1990. Foundations of Social Theory. Cambridge, MA: Harvard University Press. 
Coleman and Fararo. 1992. "Introduction.” Pp. ix-xxii in Rational Choice Theory, edited by James S. Coleman and Thomas J. Fararo. Newbury Park, CA: Sage.

Collins, Randall. 1979. The Credential Society. New York : Academic Press.

----. 1980. "Weber's Last Theory of Capitalism: A Systematization." American Sociological Review 45:925-942.

-----. 1981. "The Microfoundations of Macrosociology." American Journal of Sociology 85: 984-1014.

-----. 1986. Weberian Sociological Theory. Cambridge: Cambridge University Press.

-----. 1988. Theoretical Sociology. San Diego: Harcourt Brace Jovanovich.

-----. 1999. Macrohistory. Stanford: Stanford University Press.

-----. 2004. Interaction Ritual Chains. Princeton: Princeton University Press.

Drori, Gili, et al. 2003. Science in the Modern World Polity: Institutionalization and

Globalization, by Gili S. Drori, John W. Meyer, Francisco O. Ramirez, and Evan Schofer. Stanford: Stanford University Press.

Durkheim, Emile. [1898] 1969. "Individualism and the Intellectuals.” Political Studies 17: 14-30.

Eisenstadt, S. N. 1965. "Transformation of Social, Political, and Cultural Orders in Modernization." American Sociological Review 30: 659-673.

-----. 1968a. "Social Institutions: The Concept." Pp. 409-421 in International

Encyclopedia of the Social Sciences, volume 14, edited by D. L. Sills. New York: Macmillan. 
-----. 1968b. "The Protestant Ethic Thesis in an Analytical and Comparative

Framework." Pp. 3-45 in The Protestant Ethic and Modernization, edited by S. N.

Eisenstadt. New York: Basic Books.

-----. 1999. Fundamentalism, Sectarianism, and Revolution. Cambridge: Cambridge University Press.

Elster, Jon. 1989. Nuts and Bolts for the Social Sciences. Cambridge: Cambridge University Press.

Engerman, Stanley L. 2000. "Max Weber as Economist and Economic Historian.” Pp. 256-271 in The Cambridge Companion to Weber, edited by Stephen Turner. Cambridge: Cambridge University Press.

Esser, Hartmut. 1994. "Explanatory Sociology.” Soziologie 3: 177-190.

Fararo, Thomas. 1992. The Meaning of General Theoretical Sociology. Cambridge: Cambridge University Press.

Fodor, Jerry. 1997. "Special Sciences: Still Autonomous After All These Years." Philosophical Perspectives 11: 149-163.

Garfinkel, Alan. 1981. Forms of Explanation. New Haven: Yale University Press.

Gell-Mann, Murray. 1994. The Quark and the Jaguar: Adventures in the Simple and the Complex. New York: W.H. Freeman.

Gerring, John. 2007. "Review Article: The Mechanismic Worldview: Thinking Inside the Box." British Journal of Political Science. 38: 161-179.

Goldstein, L.J. 1973. "The Inadequacy of the Principle of Methodological Individualism.” Pp. 264-276 in Modes of Individualism and Collectivism, edited by J. O’Neill. London: Heinemann. 
Gordon, Scott. 1993. The History and Philosophy of Social Science. Milton Park, UK: Routledge.

Gorski, Philip S. 2003. The Disciplinary Revolution. Chicago: University of Chicago Press.

-----. 2005. "The Little Divergence: The Protestant Reformation and Economic Hegemony in Early Modern Europe.” Pp. 165-190 in The Protestant Ethic Turns 100. Boulder: Paradigm Publishers.

Granovetter, Mark. 1973. "The Strength of Weak Ties.” American Journal of Sociology 78: 1360-1380.

Hamilton, Alastair. 2000. "Max Weber's Protestant Ethic and the Spirit of Capitalism." Pp. 151-171 in The Cambridge Companion to Weber, edited by Stephen Turner. Cambridge: Cambridge University Press.

Hannan, Michael. 1992. "Rationality and Robustness in Multilevel Systems." Pp. 120136 in Rational Choice Theory, edited by James S. Coleman and Thomas J. Fararo. Newbury Park, CA: Sage Publications.

Hannan, Michael, and John Freeman. 1986. “The Ecology of Organizations: Structural Inertia and Organizational Change.” Pp. 151-172 in Approaches to Social Theory, edited by Siegwart Lindenberg, James S. Coleman, and Stefan Nowak. New York: Russell Sage Foundation.

-----. 1989. Organizational Ecology. Cambridge, MA: Harvard University Press.

Hawthorn, Geoffrey. 1987. Enlightenment and Despair: A History of Social Theory. Cambridge: Cambridge University Press.

Hechter, Michael. 1989. "Rational Choice Foundations of Social Order." Pp. 60-81 in 
Jonathan H. Turner (ed.) Theory-Building in Sociology. Newbury Park, CA: Sage. Hedström, Peter, and Richard Swedberg. 1998. "Social Mechanisms: An Introductory Essay.” Pp. 1-31 in Social Mechanisms, edited by Peter Hedström and Richard Swedberg. Cambridge: Cambridge University Press.

Hernes, Gudmund. 1976. "Structural Change in Social Processes." Sociology. 82: 513-54.

-----. 1989. "The Logic of the Protestant Ethic.” Journal of Rationality and Society 1: 122-161.

Homans, George. 1961. Social Behavior: Its Elementary Forms. New York: Harcourt, Brace, and World.

Huff, Toby. 2003. The Rise of Early Modern Science, $2^{\text {nd }}$ edition. Cambridge: Cambridge University Press.

Jepperson, Ronald, and John W. Meyer. 2007. “Analytical Individualism and the Explanation of Macrosocial Change: From Weber to Theories of Global Capitalism.” Pp. 273-304 in On Capitalism, edited by Victor Nee and Richard Swedberg. Stanford: Stanford University Press.

Jones, E. L. 1981. The European Miracle. New York: Cambridge.

Kahneman, Daniel, Paul Slovic, and Amos Tversky. 1982. Judgment Under Uncertainty. New York: Cambridge University Press.

Kalberg, Stephen. 1996. “On the Neglect of Weber's Protestant Ethic as a Theoretical Treatise: Demarcating the Parameters of Postwar American Sociological Theory." Sociological Theory 14/1: 49-70. 
Kessler, Ronald C. 1997. "The Effects of Stressful Life Events on Depression.” Annual Review of Psychology 48: 191-214.

Kessler, Ronald, and Jane McLeod. 1984. "Sex Differences in Vulnerability to Undesirable Life Events." American Sociological Review 49: 620-631.

Kincaid, Harold. 1996. Philosophical Foundations of the Social Sciences. Cambridge: Cambridge University Press.

Knorr-Cetina, K. 1981. "The micro-sociological challenge of macro-sociology: towards a reconstruction of social theory and methodology.” Pp. 1-48 in Advances in Social Theory and Methodology, edited by K. Knorr-Cetina and A. V. Cicourel. Boston: Routledge \&Kegan Paul.

Kontopoulos, Kyriakos M. 1993. The Logics of Social Structure. Cambridge: Cambridge University Press.

Kurzweil, Edith. 1989. The Freudians: A Comparative Perspective. New Haven, CT: Yale University Press.

Landes, David S. 1998. The Wealth and Poverty of Nations. New York: Norton.

Levine, Donald N. 1995. Visions of the Sociological Tradition. Chicago: University of Chicago Press.

Little, Daniel. 2007. "Levels of the Social.” Pp. 343-372 in Philosophy of Anthropology and Sociology, edited by S. P. Turner and M. W. Risjord. Amsterdam: Elsevier.

Lukes, Steven. 1977. Essays in Social Theory. New York: Columbia University Press. 
Lüthy, Herbert. 1968. “Once Again: Calvinism and Capitalism.” Pp. 87-108 in The Protestant Ethic and Modernization, edited by S. N. Eisenstadt. New York: Basic Books.

MacKinnon, Malcolm H. 1993. "The Longevity of the Thesis: A Critique of the Critics.” Pp. 211-244 in Weber's Protestant Ethic, edited by Hartmut Lehmann and Guenther Roth. Cambridge: Cambridge University Press.

Mahoney, James. 2001. "Beyond correlational analysis: Recent innovations in theory and method. Sociological Forum 16: 575-593.

Maddison, Angus. 2001. The World Economy: A Millennial Perspective. Paris: Organization for Economic Cooperation and Development.

Mann, Michael. 1986. The Sources of Social Power, volume 1. Cambridge: Cambridge University Press.

Mayhew, Bruce H. 1980. “Structuralism versus Individualism.” Social Forces 59: 335$375,627-648$.

Mayntz, Renate. 2003. "Mechanisms in the Analysis of Social Macro-Phenomena." Philosophy of the Social Sciences 34: 237-259.

McClelland, David. 1967. The Achieving Society. New York: Free Press. McNeill, William. 1963. The Rise of the West. Chicago: University of Chicago Press. -----. 1974. The Shape of European History. New York: Oxford University Press. Meyer, John W. 1977. "The Effects of Education as an Institution." American Journal of Sociology 83: 55-77.

Meyer, John W., and Ronald L. Jepperson. 2000. “The ‘Actors' of Modern Society: The Cultural Construction of Social Agency." Sociological Theory 18:100-120. 
Mokyr, Joel. 1992. The Lever of Riches. Oxford: Oxford University Press.

-----. 1999. "Eurocentricity Triumphant." Published online in The American Historical $\underline{\text { Review } 104(4) .}$

Münch, Richard. 1986. "The American Creed in Sociological Theory: Exchange, Negotiated Order, Accommodated Individualism, and Contingency." Sociological Theory 4: 41-60.

-----. 1987. "The Interpenetration of Microinteraction and Macrostructures in a Complex and Contingent Institutional Order.” Pp. 319-336 in J.C. Alexander et al. (eds.), The Micro-Macro Link. Berkeley: University of California Press.

-----. 1994. Sociological Theory: From the 1850s to the 1920s. Chicago: Nelson-Hall. New York: Plenum.

-----. 2001. The Ethics of Modernity: Formation and Transformation in Britain, France, Germany, and the United States. London: Rowman and Littlefield.

Münch, Richard, and N. Smelser. 1987. "Relating the Micro and Macro." Pp. 356-388 in J.C. Alexander et al. (eds.), The Micro-Macro Link. Berkeley: University of California Press.

Padgett, John F., and Paul D. McLean. 2006. "Organizational Invention and Elite Transformation: The Birth of Partnership Systems in Renaissance Florence.” American Journal of Sociology 111: 1463-1568.

Parkin, Frank. 1982. Max Weber. London: Routledge.

Parsons, Talcott. 1937. The Structure of Social Action. New York: McGraw-Hill.

------. 1951. The Social System. New York: Free Press. 
-----. 1947. "Introduction.” Pp. 3-86 in Max Weber: The Theory of Social and

Economic Organization, translated by A. M. Henderson and Talcott Parsons, and edited with an introduction by Talcott Parsons. New York: Free Press.

-----. 1977. The Evolution of Societies. Englewood Cliffs, NJ: Prentice Hall.

Poggi, Gianfranco. 1983. Calvinism and the Capitalist Spirit: Max's Weber's Protestant

Ethic. Amherst: The University of Massachusetts Press.

Pomeranz, Kenneth. 2000. The Great Divergence. Princeton: Princeton University Press.

Przeworski, Adam, and Michael Wallerstein. 1982. "The Structure of Class Conflict in Democratic and Capitalist Societies.” American Political Science Review 76: 215238.

Sawyer, R. Keith. 2002. "Durkheim's Dilemma: Toward a Sociology of Emergence." Sociological Theory 20/2: 227-247.

-----. 2003. "Nonreductive individualism Part II: Social causation.” Philosophy of the Social Sciences 33/2: 203-224.

Schelling, Thomas. 1971. "Dynamic Models of Segregation." Journal of Mathematical Sociology 1: 143-186.

Simon, Herbert. 1962. "The Architecture of Complexity." Proceedings of the American Philosophical Society 106: 467-482.

Skocpol, Theda, and Ann Shola Orloff. 1986. "Explaining the Origins of Welfare States: A Comparison of Britain and the United States, 1880s-1920s.” Pp. 229-258 in Approaches to Social Theory, edited by Siegwart Lindenberg, James S. Coleman, and Stefan Nowak. New York: Russell Sage Foundation. 
Stinchcombe, Arthur. 1968 Constructing Social Theories, New York, Harcourt, Brace \& World.

------. 1991. "The Conditions of Fruitfulness of Theorizing about Mechanisms in Social Science." Philosophy of the Social Sciences 21: 367-388.

Strayer, Joseph. 1973. The Medieval Origins of the Modern State. Princeton: Princeton University Press.

Thompson, E. P. 1963. The Making of the English Working Class. New York: Pantheon Books.

Thomson, Garrett. 2003. On Philosophy. Toronto: Wadsworth.

Tilly, Charles. 1990. Coercion, Capital, and European States. Cambridge, MA: Blackwell.

-----. 2001. "Mechanisms in Political Processes." Annual Review of Political Science 4: 21-41.

Toulmin, Stephen. 1992. Cosmopolis: The Hidden Agenda of Modernity. Chicago: The University of Chicago Press.

Townsend, J.M. 1978. Cultural Conceptions and Mental Illness: A Comparison of Germany and the U.S. Chicago: University of Chicago Press.

Turner, Jonathan H., and David E. Boyns. 2002. "The Return of Grand Theory.” Pp. 353-378 in Handbook of Sociological Theory, edited by Jonathan H. Turner. (New York: Kluwer Academic / Plenum Publishers).

Trevor-Roper, H. R. 1967. Religion, the Reformation and Social Change. London: Macmillan. 
Udehn, Lars. 2002. “The Changing Face of Methodological Individualism.” Annual Review of Sociology 28: 479-507.

Varenne, Hervé. 1984. "Collective Representation in American Anthropological Conversations: Individual and Culture." Current Anthropology 25: 281-300.

Wallerstein, Immanuel. 1974. The Modern World System, volume 1. New York: Academic Press.

Walzer, Michael. 1965. The Revolution of the Saints. Cambridge, MA: Harvard University Press.

Watkins, J. W. N. 1952. “The Principle of Methodological Individualism.” British Journal of the Philosophy of Science 3: 186-189.

-----. 1957. "Historical Explanation in the Social Sciences." British Journal for the Philosophy of Science. 8: 104-117.

Weber, Max. [1904/5] 1996. The Protestant Ethic and the Spirit of Capitalism. Los Angeles: Roxbury.

-----. [1920] 1996. "Max Weber's Introduction to the Sociology of Religion (1920)." Pp. 13-31 in The Protestant Ethic and the Spirit of Capitalism, by Max Weber. Los Angeles: Roxbury.

-----. [1923] 1950. General Economic History. Glencoe, IL: The Free Press.

Werner, Karl Ferdinand. 1988. "Political and Social Structures of the West." Pp. 169184 in Europe and the Rise of Capitalism, edited by Jean Baechler, John A. Hall, and Michael Mann. Oxford: Basil Blackwell.

White, Harrison. 1970. Chains of Opportunity. Cambridge: Harvard University Press. ------. 1992. Identity and Control. Princeton: Princeton University Press. 
White, Lynn, Jr. 1978. Medieval Religion and Technology. Berkeley: University of California Press.

Wilson, E. O. 1998. Consilience. New York: Knopf.

Wippler, Reinhard. 1978. “The Structural-Individualistic Approach in Dutch Sociology." Netherlands Journal of Sociology 4: 135-155.

Wippler, Reinhard, and Siegwart Lindenberg. 1987. “Collective Phenomena and Rational Choice.” Pp. 135-152 in The Micro-Macro Link, edited by Jeffrey C. Alexander, Bernhard Giesen, Richard Münch, and Neil J. Smelser. Berkeley: University of California Press.

Wuthnow, Robert. 1989. Communities of Discourse: Ideology and Social Structure in the Reformation, the Enlightenment, and European Socialism. Harvard: Harvard University Press.

Zahle, Julie. 2007. "Holism and Supervenience." Pp. 311-342 in Philosophy of Anthropology and Sociology, edited by S. P. Turner and M. W. Risjord. Amsterdam: Elsevier.

Zaret, David. 1989. "Religion and the Rise of Liberal-Democratic Ideology in $17^{\text {th }}$ Century England." American Sociological Review 54: 163-179.

Zetterberg, Hans L. 1965. On Theory and Verification in Sociology, $3^{\text {rd }}$ edition. Totowa, NJ: Bedminster Press.

-----. 1993. "Rationalism and Capitalism: Max Weber." Chapter 2 of the web publication, European Proponents of Sociology Prior To World War. Copyright 1993 Hans L. Zetterberg. 


\section{FOOTNOTES}

${ }^{1}$ When analysts use the terms "macro," "micro," and sometimes "meso," it is easy to conflate complexity, in the sense just described, with scale - that is, spatial size or extension in time. But scale and complexity are analytically independent dimensions in principle. For instance, in social science, one might refer to the "collective level" (for example, the polity) of, say, families--a fairly "small" ("micro") unit in scalar terms. One might also refer to a "micro-level" (perhaps specific commodity chains) of the world system, a "big" ("macro") unit. In this article we focus on levels of causal processes differentiated by complexity-the fundamental denotation, we think, in the philosophy of science.

${ }^{2}$ The example of game theory makes clear that aggregation of behaviors is not always an element in more individual-level and "elementary social" imagery (as Coleman stressed [1987]). For instance, a game theoretic model of "class conflict," such as the one proposed by Przeworski and Wallerstein (1982), employs economic classes as units. Their interaction does not primarily affect society via aggregation. Yet the core model is a bargaining game between two stylized unitary actors, hence a relatively "simple" social interaction in the strict sense just defined.

3 The boundaries between the three "levels" necessarily blur. Structural ideas blur on the one side with individual and elementary social ones. For instance, ideas about social movements blur with ideas of "collective behavior," the latter having a more individualist cast. Ideas of organizational and professional cultures blur with ideas about cultures having broader expanse and longer histories (i.e., more institutional ideas). 
${ }^{4}$ We are indebted to Ann Swidler for her emphasis upon this point.

${ }^{5}$ This point about reduction follows current philosophical literature. For a representative example: "The very existence of the special sciences [i.e., those other than physics] testifies to reliable macrolevel regularities that are realized by mechanisms whose physical substance is quite typically heterogeneous. Does anybody really doubt that mountains are made of all sorts of stuff? Does anybody really think that, since they are, generalizations about mountains-as-such won't continue to serve geology in good stead? Damn near everything we know about the world suggests that unimaginably complicated to-ings and fro-ings of bits and pieces at the extreme microlevel manage somehow to converge on stable macro-level properties" (Fodor 1997: 160). 